\title{
Porque será a Química a ciência esquecida?
}

Apesar do facto da Química ser a ciência fundamental, a ciência que tem tido mais impacto na humanidade do que todas as outras ciências combinadas, ela nunca produziu um divulgador empolgante como um Lewis Thomas, ou Stephen Jay Gould ou Carl Sagan, ou Stephen Hawking. Também nunca atraíu a atenção que merece por parte dos jornalistas responsáveis pelos "cadernos" de ciência na imprensa em geral.

A percepção dos "media" sobre a Química, foi o tópico de um simpósio patrocinado pelo "Young Chemists Committee" da Reunião Nacional da American Chemical Society que teve lugar em Anaheim, Califórnia. O escritor destas linhas(*) foi convidado para participar neste simpósio para chamar à atenção sobre a indiferença dos meios de comunicação social relativamente à química.

De certa forma, a Química é vítima do seu próprio sucesso. Ela prejudica-se em certa medida, devido ao trabalho de um químico ser muitas vezes um meio para chegar a um fim: um composto ou um material específico. A Química é, eminentemente, uma ciência práctica.

A Química tem outro problema, o qual está relacionado com o facto de estar constantemente a perder a grande maioria das suas áreas de interesse para outras disciplinas. A revolução biotecnológica apareceu quando moléculas biológicas tal como o DNA começaram a ser manipuladas por químicos. No entanto, as pessoas não pensam na Biotecnologia como uma subdisciplina da Química.

Os problemas relacionados com a forma como a Química é entendida pela imprensa e pelo público em geral, vão para além do facto desta ser uma ciência práctica que continua a perder parte de si mesma para outras disciplinas. A Química é a ciência mais rigorosa, sendo por isso mesmo, à priori, difícil de se fazer comunicar, especialmente para não químicos. E o rigor desta ciência parece tomar os próprios químicos reluctantes em ousar ir para além da sua própria especialidade na forma como expõem a sua ciência. Ambas as tendências roubam ao público a noção intuitiva da beleza e do poder da Química.

Será a ciência mais rigorosa? Muita gente, particularmente físicos, argumentariam em desfavor desta afirmação. A Física baseia-se em rigor na Matemática, Então, como pode a
Química ser mais rigorosa que a Física. A Física pode basear-se na lógica rigorosa da Matemática, mas a Química fundamenta-se no ultra rigor da realidade. Considere-se um exemplo: durante os últimos dois anos, pelo menos, os físicos têm admitido que não conseguem encontrar $90 \%$ da matéria que a suas teorias prevêm que deveria existir no universo. Isto parece não os preocupar. Parece não thes sugerir, que as suas teorias, por mais belas e matematicamente rigorosas que sejam, possam estar erradas.

Uma elegante teoria química que desse origem a previsões que estivessem imprecisas numa ordem de magnitude, teria sido simplesmente julgada como errada e, consequentemente, esquecida.

Os biólogos, exeptuando os biólogos moleculares (que deveriam ser denominados "biólogos químicos"), tratam de sistemas que são tão complexos que só lhes permitem ter uma ínfima e rudimentar noção de como eles funcionam. Os biólogos não se advogam do direito de considerar a sua ciência como sendo tão precisa como a Química.

Os químicos manipulam a matéria, a qual é real. Os experimentalistas estão presos aos resultados de tal manipulação. Eles podem observar o que está a ocorrer numa experiência, e se nāo de uma forma directa, pelo menos com o auxílio da fantástica instrumentação que tem sido desenvolvida nas últimas duas décadas. Sabem perfeitamente quando é que uma experiência funcionou e quando é que outra falhou. E os químicos teóricos estão completamente maneatados pelos resultados daquelas experiências. As suas teorias têm que, obrigatoriamente, estar de acordo com a realidade experimental.

Esta distinção clara entre a Química e as outras ciências parece ter produzido um efeito pernicioso nos químicos. Enquanto os físicos, os biólogos, os geólogos e os cientistas planetários, todos parecem ter a capacidade de exaltar poeticamente as suas ciências, os químicos parecem ter, pelo menos aparentemente, perdido o encanto dentro do labirinto dos detalhes da realidade química. Enquanto que a imprecisão e a dúvida parecem ter permitido "libertar" os outros cientistas, a precisão e o rigor experimental algemaram os químicos. A maioria da ciência, que não química, é especulativa. Questões científicas, que vão desde assuntos à grande escala como seja a estrutura do universo, passando pela geologia da Terra e acabando na forma como funciona o cérebro humano. são altamente especulativas na sua essência. Aqui, observação e experiência contribuem para essa especulação, mas existe também uma forte componente de imaginação envolvida nas histórias que físicos, geólogos e neurofisiólogos e outros cientistas contam. Por isto, os cientistas destas áreas parecem sentir-se mais confortáveis do que os químicos relativamente às suas incertezas e à possibilidade de que possam estar errados.

A Química também é especulativa, pois claro, mas os químicos não gostam de pensar nela como tal. A maravilha da Química encontra-se. fundamentalmente, nos detalhes. E, infelizmente, a maravilha dos detalhes é quase impossível de comunicar a alguém que não seja versado em Ciência. Bastante frequentemente, discutindo a sua ciência, os químicos inundam a audiência com detalhes em vez de a apresentar de uma forma concisa e empolgante.

Como resultado, muitos dos avanços fantásticos da Química, avanços esses que têm tido e estão a ter fortes efeitos positivos na qualidade da vida humana, têm passado indiferentes nos meios da comunicação em geral. Porque será que a Química é a ciência esquecida? Porque somente uma ínfima parcela destas histórias empolgantes foi contada ao público. A história fabulosa da criação e transformação dos polímeros desde os plásticos baratos até aos materiais de alta tecnologia não foi contada. $\mathrm{A}$ incrível saga da Química medicinal deste século não foi contada. O papel da Química na transformação da Biologia como uma ciência largamente descritiva para ver uma verdadeira ciência Física não foi contado.

Estas histórias precisam de ser contadas em termos que permitam aos não cientistas entendê-las. E serem contadas por bons contadores de histórias, capazes de incorporar nos seus contos tanto a epopeia humana da descoberta científica como os próprios princípios químicos que estão por detrás das descobertas.

(") Rudy Baum in "Science Insights", Chemistry el Engineering (1995). April 24, 49. Tradução autorizada 